\title{
NAISET TARVITSEVAT KOKONAISVALTAISTA PÄIHDEHOITOA ${ }^{1}$
}

Teija Karttunen: YTT, sosiaalityön esimies, Vantaan kaupunki

teija.e.karttunen@jyu.fi

Janus vol. 28 (1) 2020, 77-84

Luin jokin aika sitten Anja Snellmanin (2013) romaanin "Pääoma". Se kertoo Snellmanin 67-vuotiaana kuolleesta sisaresta, Marusta. Kirjan kerronta kutoutuu Marun, erityisen ja erilaisen sisaren elämän ja sitä sävyttäneen salaisuuden selvittämisen ympärille. Snellman kuvaa, miten jo lapsena yritti hahmottaa Marulle diagnooseja sekä selityksiä sisaren piirteille ja sairauksille lähikirjaston paksujen kirjojen äärellä. Etsinnöissään Snellman törmää kirjainyhdistelmään FAS, fetaalialkoholioireyhtymä eli sikiön alkoholioireyhtymä. Snellman pysähtyy, pelästyy ja pohtii: joiko äiti sittenkin ja miten paljon, jäikö äidin tissuttelu riehuvan humalaisen isän varjoon, oliko äiti kenties lääkeriippuvainen tai mistä lääkäri ja kätilö vaikenivat katsoessaan vastasyntynyttä Marua? Snellman vertailee kirjojen kuvia sisareensa, leikkaa kuvat talteen itselleen ja vääntää piilossa omille lapsenkasvoilleen FAS-ilmettä. Lopullista vastausta ei tule; Marun salaisuuteen ei tule selvyyttä. Snellmanin osin metaforinen kerronta, Marun piirteiden ja vammojen syiden selvittely-yritykset ja äidin päihteiden käytön puntarointi nostavat kuitenkin esille yhden naisten päihdeongelmiin liittyvän kipeän kysymyksen, nimittäin sikiövauriot ja lapsille koituvat haitat. Näiden teemojen ympärille kiteytyy usein myös se julkinen ja poliittinen keskustelu, kun aiheena ovat naisten päihdeongelmat ja niiden hoito. $\mathrm{Ne}$ ovat kiistatta eettisesti vaikeita aiheita, ja äitien päihdeongelmat haastavat monin tavoin sosiaali- ja terveydenhuollon ammattilaisten ymmärrystä, asenteita ja toimintatapoja.

Naisten päihdeongelmat ovat kuitenkin laajempi ja monimutkaisempi kuin sikiövaurioihin, lastensuojeluun tai äitiyteen palautuva kysymys. Naisten päihdeongelmissa ei myöskään ole kyse vain lääketieteellisesti diagnosoidusta riippuvuudesta sairautena, yksilön persoonallisuuspiirteistä, terveyshaitoista tai addiktiivisesta käyttäytymisestä. Naisten päihdeongelmat ovat yhteydessä sosiaalisiin suhteisiin, kulttuurisiin ja yhteiskunnallisiin tekijöihin, sosiaalisten ongelmien kasautumiseen ja niiden ylisukupolviseen ketjuuntumiseen. Monen juovan ja aineita käyttävän naisen elämähistoriasta paljastuu kasautunutta huono-osaisuutta, menetyksïa, kurjuutta, hätää ja vaille jäämistä, toisinaan jo lapsuudessa alkanut laitoskierre, kokemuksia osattomuudesta ja turvattomuudesta. Yleisesti ottaen pidän kuitenkin ongelmallisena, jos päihdeongelmaisista naisista esitetään yksipuolista kuvaa eri tavoin heikossa asemassa olevina ja päihdeongelman leimaamina, jolloin heistä tulee "toisia" - ja "niitä muita", joiden elämä ei tavallisen kansalaisen todellisuutta kosketa. Päihdeongelmasta tulee silloin vain tiettyjä ihmisiä koskettava, ja esimerkiksi tietyn sosiaalisen 
aseman voidaan kuvitella tekevän lähes immuuniksi päihdeongelman kehittymiselle. Naisten toisistaan poikkeavat tilanteet ja lähtökohdat sekä ongelmien vakavuuden vaihtelut eivät tuota perustetta puhua päihdeongelmaisista naisista kategorisesti tietynlaisena ryhmänä.

Olen tutkimuksessani pyrkinyt ymmärtämään, mitä sellaista naisten päihdeongelmiin ja niiden hoitoon liittyy, jota perinteisillä päihdehoito-ohjelmilla ei kenties voida tavoittaa. Päihdeongelmat ja niiden hoito ovat nimittäin varsin pitkään olleet sukupuolen merkityksen sivuuttavia, ja hoito-ohjelmat on rakennettu paljolti miesten lähtökohdista käsin (Saarnio 2002). Ymmärtämällä naisten päihdeongelmien syvällisempää luonnetta voimme päästä myös toimivan hoidon ja sen ulottuvuuksien jäljille.

Tutkimukseni tehtävänä on ollut tarkastella naiserityistä päihdehoidon interventiota ja sen ulottuvuuksien toteutumista laitoshoidossa. Naiserityisyydellä tarkoitan kokonaisvaltaista lähestymistapaa naisten päihdeongelmiin ja niiden hoitoon. Olen jäsentänyt naiserityisen päihdehoidon intervention ulottuvuuksia aikaisemman tutkimuksen ja etnografisen kenttätyön muodostaman synteesin kautta. Sen keskeiset ulottuvuudet liittyvät (1) naiseuden ja sukupuolen merkityksen ymmärtämiseen; (2) kehollisuuden ja traumatisoitumisen tematiikkaan; (3) yksilön sisäiseen kokemusmaailmaan paikantuviin identiteetin, tunteiden ja mielenterveyden kysymyksiin; (4) sosiaalisiin suhteisiin sekä (5) päihderiippuvuuteen ja yksilökohtaiseen muutostyöhön. Näiden ulottuvuuksien kautta olen ana- lysoinut empiiristä aineistoani, jonka olen kerännyt etnografista menetelmää soveltaen erään päihdehoitolaitoksen naistenyhteisössä. Tulosteni ymmärtämisen kannalta on olennaista käsittää, että yhteisö ja interventio ovat tässä tiiviisti sidoksissa toisiinsa. Tutkimuksessani yhteisön kuvaus kertoo myös interventiosta ja sen piirteistä sekä naiserityisen päihdehoidon ulottuvuuksien ilmenemisestä juuri tässä yhteisössä. Yhteisö, sen arki ja tapahtumat kulkevat läpi koko empiirisen aineiston analyysin ja tulosten esittämisen. Yhteisö on tutkimuksessani sekä hoidon rakenne että tietoinen hoidon väline.

Tutkimukseni tulosten perusteella haluan nostaa esille joitakin valikoituja teemoja. Ne avaavat naisten päihdeongelmien ja niiden hoidon kysymyksiä yksilön mielen, kehon ja sosiaalisen näkökulman kautta.

Ensinnäkin pidän tärkeänä kiinnittää huomiota yksilön sisäisen kokemusmaailman ja mielen tasolle palautuvien kysymysten käsittelyyn. Tällöin puhumme minään, identiteettiin, tunne-elämään ja psyykkiseen hyvinvointiin liittyvästä aihekokonaisuudesta. Tutkimusten perusteella tiedetään, että naisten päihdeongelmien yhteydessä esiintyy usein erilaisia mielenterveyden ongelmia ja psykiatrisia oireita, kuten masennusta, kaksisuuntaista mielialahäiriötä, ahdistuneisuutta, fobioita, syömishäiriöitä tai pakko-oireita. Toisaalta turvallinen yhteisö sallii ja mahdollistaa erimuotoisen oireilun, sen ilmenemisen sekä sietää poikkeavuutta. Samalla se tarjoaa oireille kohtaamisen ja käsittelyn mahdollisuuksia ilman päihteitä. Yhteisössä toiset ihmiset tuottavat tukea ja turvaa. Naistenyhteisön työs- 
kentelyssä korostui erilaisista oireista tietoiseksi tuleminen, niiden sietämisen ja hallinnan opettelu käytännön tilanteissa ja etäisyyden ottaminen. Asiakkaita haastettiin pohtimaan, oliko oma oireilu toisinaan jollain tavalla tarkoituksenmukaista. Koettuja oireita, niille annettuja syitä ja selityksiä ei pidetty itsestään selvinä ja annettuina vaan niitä kyseenalaistettiin. Työskentelyssä pyrittiin lisäämään asiakkaiden ymmärrystä omasta tilanteesta ja reagointitavoista ja toisaalta tuottamaan onnistumisen kokemuksia esimerkiksi erilaisten altistamistilanteiden kautta.

Emootioiden näkökulmasta päihteet ovat voineet olla keino joko vahvistaa tai vaientaa tunteita. Toisinaan kriittiset kasvun ja kehityksen vuodet ovat ajoittuneet samaan aikaan raskaan ja rajun päihteiden käytön kanssa. Aikuisiän kypsyyttä emootioiden käsittelyssä ei ole saavutettu. Tämä näkyy esimerkiksi omien tunnereaktioiden hallinnassa ja tunnepuheen sisällöissä. Sisäistetty ja opittu tapa kuvata omia tunnetiloja voi olla hyvin alatyylinen tai tunteita voi olla vaikea nimetä ja tunnistaa. Hoidossa voidaan tukea tunnesäätelyn kehittymistä eli sitä, miten yksilö havainnoi, ilmaisee ja säätelee tunteitaan tarkoituksenmukaisella tavalla. Tunnesäätelyn vahvistaminen hoidossa on perusteltua siksi, että kehittynyt tunnesäätely edistää yksilön kykyä toimia kohti oman elämän päämääriä, kuten päihteettömyyttä.Tunnesäätelyä voidaan vahvistaa esimerkiksi mielikuvatyöskentelyllä, kirjoittamiseen ja narratiivisuuteen pohjautuvilla työtavoilla sekä taide- ja toimintaterapian lähestymistavoilla. Naistenyhteisössä tavallisissa päivittäisissä keskusteluissa asiakkaita pyydettiin esimerkiksi kuvaamaan ja täsmentämään, mitä on kun kuuluu hyvää tai ei kuulu mitään. Asiakkaita ohjattiin pysähtymään tarkastelemaan ja ylipäätään tunnistamaan eri tilanteissa virinneitä tunteita ja pohtimaan, mistä tilanteessa oli kyse ja miten se välittyi omaan toimintaan.

Sisäisen kokemusmaailman näkökulmasta minään ja identiteettiin liittyvät kysymykset ovat niin ikään olennaisia naisten päihdehoidossa. Käsitys itsestä on voinut vääristyä ja vaurioitua aikaisemmissa ihmissuhteissa. Myös päihteet muokkaavat yksilön identiteettiä ja toisaalta päihteet voivat olla keino löytää omaa, kadonnutta itseä. Päihdeongelmasta toipuminen edellyttää uudenlaisen näkemyksen muodostamista itsestä. (Niemelä 2002, 81-82; Ruisniemi 2006, 243.)

Naisten hoidon yhtenä tärkeänä tehtävänä on tukea naisen voimaantumista, oman minän vahvistumista ja sen myönteisten piirteiden löytämistä. Tutkimuksessani oman minän vahvistamisen peilauspintana toimivat toiset naiset, vertaiset ja ammattilaiset. Käytännössä esimerkiksi harjoiteltiin positiivisen palautteen antamista ja vastaanottamista, pohdittiin omia vahvuuksia tai opeteltiin oman mielipiteen esittämistä tilanteissa, joissa esimerkiksi yhdessä suunniteltiin tulevan viikon ohjelmaa. Tässä korostui työntekijöiden taito kohdata naiset arvostavalla ja kunnioittavalla tavalla siten, että naiselle muodostui kokemus siitä, että hän riittää, kelpaa ja osaa. Ei ole yhdentekevää, miten ammattilaiset asiakkaista puhuvat, esimerkiksi käytetäänkö sellaisia käsitteitä, kuten "alkoholisti", "päihdeäiti" tai "lääkkeisiin fiksoitunut". Jo puheessa tuotetaan identiteetin rakentumisen aihioita. (Kulmala 2004.) 
Aina ei ole selvää, mikä oli ensin päihde, psyykkinen kipu, emotionaalinen haava vai vaurioitunut minä. Olennaisempaa ehkä on, että ne tunnistetaan, nimetään ja että niiden dynamiikkaa päästään tutkimaan ihmisen elämäntilanteen kokonaisuudessa. Merkityksellistä tässä on kannatteleva ja kiinnipitävä hoidollinen ympäristö,jossa yksilö voi kokea tulleensa nähdyksi, kuulluksi ja hyväksytyksi omana itsenä. Oman mielen ja sen reaktioiden tutkiminen yhteisöhoidon kontekstissa tarkoittaa käytännössä sitä, että toisilta asiakkailta ja työntekijöiltä saatavan tuen, palautteen ja peilauksen avulla voidaan tutkia omaa itseä, mieltä, tunnereaktioita ja kokemuksia. Tosin se voi olla myös haastavaa ja jopa pelottavaa, kun saa suoran ja välittömän palautteen: että näin minut nähdään ja näin toimintani koetaan.

Yksi tällaisen työskentelyn edellytys tai ehto on, että ihminen on tietoinen oman mielen sisällöistä ja että hän kykenee pohtimaan omaa ja toisen ihmisen näkökulmaa ja kokemusta sekä erottamaan nämä toisistaan. Puhumme siis mentalisaatiokyvystä ja sen vahvistamisen merkityksestä. Mentalisaatio kehittyy varhaisissa ihmissuhteissa, hoivassa ja vuorovaikutuksessa. Myös muut korjaavat ja kannattelevat ihmissuhteet ja hoidolliset ympäristöt voivat tukea mentalisaation kehitystä. Miksi mentalisaatiokyky on tärkeää ja miksi sitä tulisi edistää päihdehoidossa? Näin on siitä syystä, että mentalisaatiokyky parantaa ihmisen kykyä säädellä omia tunnetiloja, rauhoittaa itseä ja tuottaa siten vakautta. Kehittynyt mentalisaatiokyky on myös suojaava tekijä kriisi- ja stressitilanteissa. (esim. Pajulo ym. 2015.) Yhteisöhoidossa voidaan osaltaan tukea asiakkaiden kykyä käsitteellistää ja sanallistaa omia sekä toisten tunteita ja reaktioita. Tällä voi olla myönteinen vaikutus asiakkaan toimintaan haastavissa ja kuormittavissa tilanteissa, joissa hän on tavallisesti reagoinut päihteiden käytöllä. Vahvistunut mentalisaatiokyky heijastuu myönteisellä tavalla päihdeongelmaisen asiakkaan toimintaan lähiympäristössä ja ihmissuhteissa eli niillä sosiaalisen elämän kentillä, joilla hänellä on varsin usein ollut ongelmia.

Käsittävän ja tuntevan mielen lisäksi yksilöllä on myös keho. Sen kautta välittyvät viestit ja kehon tapa reagoida erilaisiin ärsykkeisiin, muistoihin ja kokemuksiin. Näin päästään toiseen keskeiseen hoidolliseen kysymykseen eli kehollisuuden tematiikkaan. Tunnistamalla kehon reaktioita voidaan saada tarttumapintaa siihen, mitä psyyken alueella tapahtuu - tai jää tapahtumatta. (Tiihonen 1997; Svennevig 2003.) Päihdeongelman taustalla oleva elämä, kokemukset ja muistot ilmenevät myös kehon, sen oireiden ja tuntemusten tasolla. Tutkimuksessani kehollisuus tuli näkyviin esimerkiksi naisten erimuotoisena psykosomaattisena oireiluna, oman kehon hoitamattomuutena ja välinpitämättömyytenä sekä vaikeuksina hahmottaa kohtuullisuutta ja omia rajoja esimerkiksi syömisen ja liikunnan kaltaisilla tavallisilla elämänalueilla. Ongelmat kehollisuuden alueilla kiinnittyvät tavallisesti naisten kielteisiin käsityksiin itsestään naisena. Niitä sävyttävät usein häpeän, itseinhon ja kelpaamattomuuden tunteet. Näiden taustalla on usein verbaalista nimittelyä - kuten huorittelua - nöyryyttämistä, esineellistämistä ja alistamista, 
joiden kohteeksi naiset ovat joutuneet elämänsä eri vaiheissa. Naistenyhteisön työskentelyssä asiakkaita ohjattiin tunnistamaan ja kuulostelemaan erilaisia psykosomaattisia oireita ja esimerkiksi kokeilemaan erilaisia vaihtoehtoisia hoitotapoja, vaikkapa rentoutusta tai päähierontaa lääkkeiden käytön sijaan. Kehoon kohdistuvilla hoidoilla pyrittiin muun muassa stressin vähentämiseen, mikä puolestaan voi ehkäistä retkahdusta. Säännölliseen päivärytmiin, uneen, syömiseen ja liikuntaan liittyvällä ohjauksella tuettiin fyysistä toipumista, muiden oireiden lievittymistä ja naisten kokonaisvaltaista hyvinvointia. Tavoitteena oli myös tukea sitä, että nainen hahmotti oman kehon tuntemisen kautta oman kehonsa rajoja, joita kenelläkään ei ole oikeutta ylittää ja rikkoa.

Päihdehoidossa kohdataan naisia, jotka ovat kokeneet raakaa väkivaltaa, jotka ovat tulleet lähes tapetuiksi, joita on raiskattu, joita on lapsena seksuaalisesti hyväksikäytetty ja pahoinpidelty, jotka ovat myyneet itseään tai joita toiset ovat myyneet. Kehollisuus ulottuu siis myös erilaisiin traumaattisiin kokemuksiin, joissa keho kantaa näitä kokemuksia sanattomissa muodoissa. Traumaattinen kokemus, joka ei ole realisoitunut ja integroitunut osaksi yksilön tietoista elämänhistoriaa, heikentää yksilön psyykkistä hyvinvointia ja altistaa mielenterveyden ongelmille. Tiedostamattomuus, torjunta ja kipeys voivat johtaa trauman hoitamiseen päihteillä ja lääkkeillä. Tunteet ja kokemus vaiennetaan, oma olo ja keho rauhoitetaan kemiallisesti tai esimerkiksi viiltelemällä. Keho reagoi hallitsemattomasti ja epämääräisesti, kun tietoista yhteyttä muistoihin ja tapahtumiin ei ole. (Suokas-Cunliffe 2006a; 2006b.) Päihdehoidossa voidaan erilaisin kehollisuuteen kohdistuvin työtavoin edistää tietoisuutta omista oireista, kehon tuntemuksista ja niiden taustalla olevista kokemuksista.

Trauma ei vääristä ainoastaan mieltä suojaavien mekanismien toimintaa ja altista jatkuvalle mielen "hälytystilalle" tai somatisoinnille. Trauman sosiaalinen ulottuvuus heijastuu ihmisen sosiaalisen toimintakyvyn tasolle ja ilmenee vaikeuksina toimia arjen tavanomaisissa tilanteissa, paikoissa, rutiineissa sekä ihmissuhteissa. Trauma voi jähmettää ja halvaannuttaa sosiaalisesti ja nujertaa uskon omaan toimintakykyyn.

Traumanäkökulmasta olennaista työskentelyssä oli työntekijöiden pyrkimys vakauttavaan ja nykytilanteeseen pysäyttävään toimintaan. Tärkeitä olivat arjen rutiinit, niistä kiinni pitäminen ja niiden toistuvuus sekä fyysisen ja psyykkisen turvallisuuden varmistaminen. Naistenyhteisössä suuntauduttiin vahvasti toiminnallisuuteen, yhdessä tekemiseen ja konkreettisiin asioihin siten, että asiakas koki pystyvänsä toimimaan arjen eri tilanteissa ilman psyykkisen hajoamisen ja lamaantumisen tunnetta. Samoin esimerkiksi tavallisten arjen askareiden tekemisen mahdollisuus tarjosi turvallisen siirtymän pois liian ahdistavaksi muuttuneesta tilanteesta ja etäisyyden ottamisen. Olennaista oli työntekijöiden taito pysyä itse rauhallisena ja pukea sanoiksi tilannetta, normalisoida asiakkaan reaktioita ja ohjata asiakasta pysymään nykyhetkessä.

Lopuksi siirryn mielen sisäisen kokemusmaailman ja kehon kautta siihen kolmanteen keskeiseen teemaan, jonka halusin nostaa esille, eli päihdeongel- 
man sosiaalisen ulottuvuuteen. Sosiaalinen näkökulma päihdeongelmiin ymmärtää ne minään liittyvien yhteyksien ja sidosten kautta.Yksilö siis muodostaa suhteen elämän eri osa-alueisiin, kuten työhön, harrastuksiin, puolisoon ja perheeseen. Nämä osa-alueet ovat suhteessa toisiinsa ja muodostavat systeemisen kokonaisuuden. Yksilön suhteissa eri elämän osa-alueisiin voi kuitenkin esiintyä heikkenemistä tai vajavaisuutta, jolloin niille saatetaan hakea kompensaatiota esimerkiksi päihteistä. Jos suhde päihteisiin muuttuu liian intensiiviseksi ja vahvaksi, syntyy epätasapainoa yksilön suhteessa muihin elämän osaalueisiin. Päihdeongelmasta kuntoutumisessa keskeistä on näiden suhteiden elvyttäminen ja palauttaminen sekä yksilön integroituminen laajempaan yhteisöön ja yhteiskuntaan. (Adams 2008.) Suhteiden korjaaminen, tasapainottaminen sekä uudelleen liittyminen ja kiinnittyminen ovat kriittinen tekijä naisten päihdeongelmista kuntoutumiselle.

Pohdin seuraavassa lyhyesti tätä liittymisen ja kiinnittymisen problematiikkaa. Yksilön sisäiset kokemukset, niiden syntymekanismit ja kerrostuminen elämänkulussa sekä kasvun ja kehityksen läheissuhteet tuottavat osaltaan valmiuksia asettautua suhteisiin toisten kanssa ja olla yhteiskunnan jäsen. (Goldberg 1999; Bardy 2002.) Nämä siis vaikuttavat yksilön sosiaaliseen olemukseen sekä yksilön ja yhteiskunnan välisen suhteen muodostumiseen. Yksilöä muokkaavat ihmissuhteet ja sosiaaliset olosuhteet paljastavat päihteidenkäytön syvällisempiä taustoja. Juuri sosiaalisiin tekijöihin ja niiden sivuuttamiseen palautuvat myös hoidon ja ennaltaehkäisyn pulmat ja se, miksi päihderiippuvuudet eivät katoa yhteiskunnasta. (Goldberg 1999, 7-8, 12-14.) Selviytyminen, reagointi, pärjääminen, ongelmanratkaisutaidot, sopeutuminen ja osallistumisen mahdollisuudet erilaisissa materiaalisissa, sosiaalisissa ja kulttuurisissa olosuhteissa kumpuavat osaltaan näistä erilaisista yksilöllisistä lähtökohdista, psykologisista kokemuksista sekä sosiaaliseen ympäristöön ja yhteisöön liittyvistä tekijöistä. Näin myös päihdehoitoon hakeutuvat naiset voivat sosiaaliselta toimintakyvyltään olla hyvin erilaisia sen mukaan, mistä he tulevat ja millaiseksi minäksi he ovat saaneet mahdollisuuden kehittyä elämää kehystäneissä olosuhteissa.

Naisten kohdalla integroitumisen haasteita voi lisätä naisten päihdeongelmiin vahvasti liittyvä häpeä, joka on hyvin kokonaisvaltaista ja voi estää hakeutumasta hoitoon. Naisten kokema häpeä muodostuu sosiaalisen leimaamisen ja moralisoinnin kautta. Kelpaamaton, huono ja oman ihmisarvon kyseenalaistava, ovat määreitä, joita naiset itsestään saattavat esittää sisäistyneen häpeän myötä. Häpeä on paitsi psyykkinen kokemus, se on myös vahvasti sosiaalista: häpeän kautta yksilö paikantaa itseään suhteessa toisiin. Häpeä vahvistaa tai heikentää yksilön kokemusta kuulumisesta ja osallisuudesta. (Scheff 2000; Covington 2002; Turunen 2004, 65.) Siksi yksilön sisäisellä kokemuksella siitä, miten hän ajattelee kelpaavansa ja täyttävänsä yhteiskunnan sukupuolistuneet rooliodotukset ja normit, on merkitystä myös naisten päihdeongelmasta kuntoutumiselle.

Tavoitteena yhteiskuntaan integroituminen ja sosiaalisiin suhteisiin kiinnit- 
tyminen on käytännössä haastava. Se konkretisoituu naisten tarpeina ja toiveina saada päihteettömiä ihmissuhteita sekä päästä kiinni niihin yhteiskunnan instituutioihin, joissa voi jälleen kokea arvostusta ja osallisuutta. Tarve liittyä ja kiinnittyä on inhimillinen. Torjutuksi tuleminen tuottaa kokemuksia kelpaamattomuudesta ja osattomuudesta. On vaikea integroitua, jos aikaisemmat kokemukset osallisuudesta ovat ohuet tai olemattomat tai jos omille pyrkimyksille ei saa vastakaikua ja sosiaalista tukea. Kuitenkin yhteiskunnan odotukset suoriutumisesta ja pärjäämisestä ovat korkeat päihdeongelmasta toipuvalle, ja kunnon kansalaisuutta määrittävät yhä vahvasti täystyöllisyys ja kouluttautuminen. Samoin suomalainen kulttuuri, joka on korostuneen päihdemyönteinen, osaa samanaikaisesti ja hyvin taitavasti sivuuttaa päihteiden kanssa vaikeuksiin joutuneet - ulkoistaen, karttaen ja yksilöä vahvasti vastuuttaen. On syytä pohtia vakavasti, mikä on se paikka ja taho,johon päihdeongelmaiset voivat ylipäätään integroitua - vai oletetaanko heidän kuntoutuvan tyhjän päälle ja mielellään silti hyvin pikaisesti ja tehokkaasti? (Mattila-Aalto 2009; Granfelt 2004; Virokannas 2013.)

Olen edellä esittänyt valikoituja näkökulmia naisten päihdeongelmien hoidossa kohdattaviin ilmiöihin. Kuten huomaatte, en käytännössä ole puhunut mitään itse päihteistä tai edes päihteiden käytön lopettamisesta. Valitsemani teemat - mieli, keho ja sosiaalinen ulottuvuus - havainnollistavat pikemminkin sitä kokonaisvaltaisuutta, joka naisten päihdeongelmia ja niiden hoitoa luonnehtii.
Erityisesti kehollisuuden, traumatisoitumisen ja häpeän tematiikka ovat korostuneesti naisten päihdeongelmiin liittyviä. Ne edellyttävät hoidolta vakauttavia ja turvallisia rakenteita sekä empatiaa ja ymmärrystä osoittavaa vuorovaikutustyyliä. Avun ja tuen vastaanottamisen vaikeudet puolestaan voivat osaltaan palautua niihin kokemuksiin, joita yksilöllä on suhteessa toisiin ja maailmaan. Hoitoon hakeutuvalla naisella ei välttämättä ole tarvittavia sisäisiä toimintamalleja tai hänellä on puutteelliset mahdollisuudet hyödyntää olemassa olevia resursseja avun ja sosiaalisen tuen vastaanottamiseksi. Kuntoutuakseen naiset tarvitsevat kokemuksia siitä, että joku uskoo heidän mahdollisuuksiinsa ja kykyihinsä ja että hoito tuo toivon näkökulmaa omaan elämään. Kuntoutumisen ydin ei siis sittenkään ole päihteiden käytön lopettamisessa. Se on pikemminkin vasta alku uudenlaiselle orientoitumiselle elämässä. Hyvin olennaisiksi kuntoutumisen prosessissa muodostuvat ne perustavaa laatua olevat kysymykset siitä, kuka ja millainen olen, miten elän ja mihin kuulun (ks. Bardy 2002). Päihdeongelmasta kuntoutumisen mahdollisuudet rakentuvat nimenomaan suhteissa, joissa ihminen voi rakentaa suhdetta itseensä ja toisiin ja joissa hän saa kokea hyväksyntää, kunnioitusta, arvostusta ja kannattelua. On myös sosiaalityön perustehtävän mukaista tukea tällaisia suhteita ja niiden muodostumista sekä tarjota kannattelevia ympäristöjä.

\section{VIITE}

1 Puheenvuoro on Jyväskylän yliopistossa 28.9.2019 tarkastetun sosiaalityön väitöskirjan lectio praecursoria. 


\section{KirjallisuUs}

Adams, Peter (2008) Fragmented intimacy. Addiction in a social world. New York: Springer. https://doi.org/10.1007/9780-387-72661-8

Bardy, Marjatta (2002) Lasten osallisuus keitä me olemme, mihin me kuulumme ja kuinka me elämme? Teoksessa Marjatta Bardy \& Minna Salmi \& Tarja Heino (toim.) Mikä lapsiamme uhkaa? Suuntaviivoja 2000-luvun lapsipoliittiseen keskusteluun. Raportteja 263. Helsinki: STAKES, 123-134.

Covington, Stephanie (2002) Helping women recover: creating gender- responsive treatment. Teoksessa Sulamith Lala Ashenberg Straussner \& Stephanie Brown (toim.) The handbook of addiction treatment for women: Theory and practice. San Francisco: Jossey-Bass, 52-73.

Goldberg, Ted (1999) Demystifying drugs. A psychosocial perspective. New York: St. Martin's Press, Inc.

Granfelt, Riitta (2004) Hetkeksi jaetut maailmat? Kokemuksia vankilasta ja tuetun asumisen yhteisöstä. Janus 12 (2), 134-154.

Karttunen, Teija (2019) Naiserityistä päihdehoitoa. Etnografinen tutkimus naisten päihdehoitolaitoksesta. JYU Dissertations 118. Jyväskylä: Jyväskylän yliopisto.

Kulmala, Anna (2004) Toiset identiteettiä rakentamassa. Yhteiskuntapolitiikka 69 (3), 231-241.

Mattila-Aalto, Minna (2009) Kuntoutusosallisuuden diagnoosi. Tutkimus entisten rappiokäyttäjien kuntoutumisen muodoista, mekanismeista ja mahdollisuuksista. Kuntoutussäätiön tutkimuksia 81. Helsinki: Kuntoutussäätiö.

Niemelä, Jorma (2002) Identiteettityö, sosiaalinen pääoma ja marginaalista murtautuminen. Teoksessa Petri Ruuskanen (toim.) Sosiaalinen pääoma ja hyvinvointi. Jyväskylä: PS-Kustannus, 76-93.
Pajulo, Marjukka \& Salo, Saara \& Pyykönen, Nina (2015) Mentalisaatio ihmistä suojaavana tekijänä. Duodecim 131 (11), 1050-1057.

Ruisniemi, Arja (2006) Minäkuvan muutos päihderiippuvuudesta toipumisessa. Tutkimus yhteisöllisestä päihdekuntoutuksesta. Tampere: Tampereen yliopisto.

Saarnio, Pekka (2002) Miehet ja naiset päihdehoidossa: kolme empiiristä tutkimustulosta. Yhteiskuntapolitiikka 67 (3), 269-273.

Scheff, Thomas (2002) Shame and the social bond: A sociological theory. Sociological Theory 18 (1), 84-99. https://doi. org/10.1111/0735-2751.00089

Snellman, Anja (2013) Pääoma. Helsinki: Otava.

Suokas-Cunliffe, Anne (2006a) Trauma omaan elämään yhdistymätön mielen loinen. Yleislääkäri 21 (5), 19-23.

Suokas-Cunliffe, Anne (2006b) Lapsuuden kompleksisen traumatisoitumisen seuraukset aikuisuudessa. Yleisläkäri 21 (6), 9-14.

Svennevig, Hanna (2003) Hyvän olon hoidot. Kosketukseen perustuvien hoitojen käyttö hyvinvoinnin ja itseymmärryksen välineenä. Tampere: Tampereen yliopisto.

Tiihonen, Arto (1997) Lihaan kirjoitettua ja ruumissa kohdattua. Teoksessa Eeva Jokinen (toim.) Ruumiin siteet. Tekstejä eroista, järjestyksestä ja sukupuolesta. Tampere:Vastapaino, 105-118.

Turunen, Kari E. (2004) Tunne-elämä. Jyväskylä: Atena.

Virokannas, Elina (2013) Vailla suojelua huumehoidossa olleiden äitien kertomuksia lapsuudenkokemuksistaan. Teoksessa Elina Virokannas \& Sanna Väyrynen (toim.) Varjoja naiseudessa. Helsinki: UNIpress, 52-82. 